
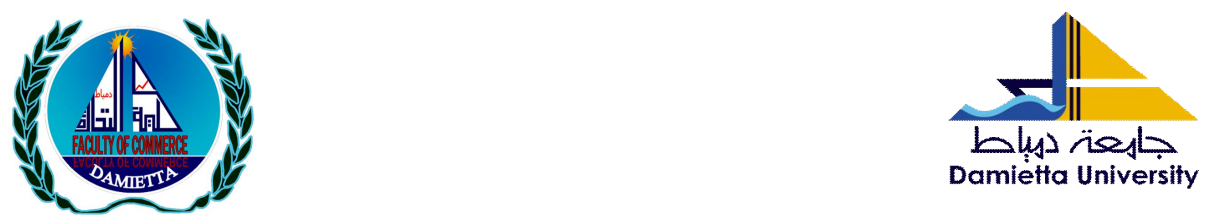

\title{
The impact of board of directors' characteristics on financial distress: Empirical evidence from Egypt using logit and discriminant analysis models.
}

\author{
Prepared by \\ Sarah Sobhy Mohamed Hassan \\ Lecturer of Business Administration \\ Faculty of Commerce - Cairo University \\ sarah_sobhy@foc.cu.edu.eg
}

Scientific gournal for Financial and Commercial Studies and

Researches (SIFCSR)

Faculty of Commerce - Damietta University

Vol.3, No.1, Part 1., January 2022

APA Citation:

Hassan, S. S. M. (2022). The impact of board of directors' characteristics on financial distress: Empirical evidence from Egypt using logit and discriminant analysis models, Scientific Journal for Financial and Commercial Studies and Research, Faculty of Commerce, Damietta University, 3(1)1, pp. 205-234.

Website: https://cfdj.journals.ekb.eg/ 
Scientific Journal for Financial and Commercial Studies and Researches

(SJFCSR) Faculty of Commerce - Damietta University

\title{
The impact of board of directors' characteristics on financial distress: Empirical evidence from Egypt using logit and discriminant analysis models
}

\author{
Sarah Sobhy Mohamed Hassan
}

\begin{abstract}
Purpose: This paper aims at investigating financial distress and explore the nature of the relationship between board of director's characteristics and financial distress in the Egyptian economy from 20152018.

Design /methodology / approach: To determine the best suitable model to express data, two models were employed in this research. The first model is multivariate discriminant analysis model introduced by Altman and Hotchkiss (2010) and logit model.

Findings: Our results suggest that the proportion of independent directors and CEO duality are found to be significant determinants for financial distress. However, board size is not a significant variable in predicting financial distress. These results have been confirmed using logistic model. On the other hand, discriminant model reveals that all the explanatory variables are significant in explaining financial distress. Increasing board size increases the probability of financial distress while CEO duality and board independence have a positive impact on financial distress probability. Depending on different criteria $\left(\mathrm{R}^{2}\right.$, classification table, ROC curve) to compare between logit model and discriminant model, it has been revealed that logit model is better in explaining financial distress.
\end{abstract}

Originality/ value: This article is one of the first to investigate whether board of directors' attributes contribute to explain of the occurrence of financial distress in the context of Egypt's economy.

Keywords: Financial distress, board of directors, corporate governance, logit model, discriminant analysis model. 


\section{Sarah Sobhy Mohamed Hassan}

\section{1- Introduction:}

In 2008-2009 the world economy faced the worst global financial crisis since the Second World War (Apergis, Bhattachage and Inekwe 2019). During the global financial crisis many companies have fallen into financial distress (Bredart 2014). This crisis has negative consequences on multinational corporations' performance. For example; sales of MNCs declined by $5 \%$ and production dropped by $16 \%$ (Apergis, et.al 2019). Also, global financial crisis has negative consequences for the stakeholders of the company either directly or indirectly. Major stakeholders are exposed to lose their initial investments, employees might lose their jobs and for sure governments will collect less taxes (Abdullah, Ma'aji and Khaw 2016). Given the impact on many parties (shareholders and financial institutions), the failure of organizations has become one of the events of special interest in economic life. As a result, financial distress prediction has become a subject of a great interest in corporate finance major (Charalambakis and Garrett 2018), (Bredart 2014).

Developing an early warning system for detecting financial distress has become essential especially after the increasing number of companies experiencing financial failure (Jabeur and Fahmi 2017). The inability to develop such warning system may lead to some negative consequences such as bankruptcy, liquidity or changing in control. (Abdullah, et.al 2016, Noor and Iskandar 2012). Jabeur and Fahmi (2017) indicated that research in the field of predicting financial distress is of great importance to different stakeholders. From the manager's point of view, the possession of forecasting tools gives managers the opportunity to review strategy and take the appropriate corrective steps. For other partners, these tools contribute to reduce information asymmetry and quickly detect the financial difficulties faced by companies.

Investigating the causes of financial distress is not a new topic. From 1960s the introduced research papers to explain financial distress are in fact an extension of Beaver $(1966,1968)$, Altman $(1968,1982)$ or Ohlson (1980). Most of previous researches focused on studying financial and accounting information using several statistical techniques. However, several scholars have argued that economic data are not adequate to explain financial distress. As a result, it became important to 
Scientific Journal for Financial and Commercial Studies and Researches (SJFCSR) Faculty of Commerce - Damietta University

include variables of governance to enhance the forecasting power of the econometric models.

On the other hand, the global financial turmoil has required shedding light on the importance of testing the relationship between corporate governance and financial distress exposure. The weakness of governance mechanisms in many companies is a major cause of many bankruptcies worldwide. The report introduced by the OECD in 2009 confirmed that weak governance in many companies is the main cause of firms' crisis. Also, the weakness of confidence in the global financial markets is due to practices of corporate governance. This has resulted in a dispute of interest between shareholders and managers on the one hand and between shareholders and board of directors on the other hand. (Baklouti, Gautier and Affes 2016). Salloum and Azoury (2012) confirmed that after the global financial crisis of giant corporations, accusations directed to board of directors because they did not do their jobs properly and efficiently.

From 1980s large amounts of research papers have focused their attention on the value of corporate governance and its important role in explaining financial distress. The importance of corporate governance in explaining financial distress have been introduced by postulates of agency theory. According to agency theory the variance of interests between management and stockholders has a negative impact in the case of crisis because managers will concentrate on short-term strategies that will maximize their personal wealth and this behaviour will create a conflict with shareholders. (Manzanqu, et.al 2015).

Although different researchers have displayed the importance of corporate governance mechanisms in explaining financial distress, they have been restricted to certain contexts (USA, China, Taiwan ...) and on legal process of financial distress. Also, corporate governance mechanisms vary between countries which justifies the importance of extension the analysis from one country to another. (Manzanque, et.al 2015).

Fich and Slezak (2008) indicated that corporate governance has two potential effects on bankruptcy. First, the emergence of many large corporate collapses introduces new evidence that accounting and 


\section{Sarah Sobhy Mohamed Hassan}

financial data can be deceptive to hide the bad performance of companies, which means that corporate governance can have an influence on the precision of accounting disclosure used to evaluate the correct situation of the company. Second, the corporate governance structure represents set of incentive contracts, so the effectiveness of management in responding to financial distress depends on the characteristics of the governance structure.

Additionally, although financial distress models were developed during 1960s, the vast majority of them considered accounting data only. From the late of 1985 to mid-1990s, some researchers began to examine the relationship between financial distress and corporate governance. The main conclusion has confirmed that dimensions of corporate governance enhance the forecasting ability of distress models. However, only a relatively few current studies have highlighted this under-investigated part of literature (Bredart 2014). Moreover, Previous studies mentioned that over the last two decades number of corporations' failure have been witnessed which led many researchers to question the strength of governance practices of different countries (Al-Tamimi 2012). Observing many companies in United States and other developed countries which suffered from financial distress gives a signal that the practices of corporate governance are not enough to prevent financial distress from happening. (Abdullah et.al 2015). Theoretically, having good corporate governance practices reduces the probability of financial distress exposure. Literature reveals that firms with good implementation of governance are well managed firms and are less likely to experience high financial distress costs (Abdullah et.al 2015). Little no of researches has scrutinized the relation between corporate governance and financial distress, and most of these few studies have focused on the impact of some accounting ratios and ignored the impact of corporate governance characteristics (dimensions) such as board structure on the probability of financial distress. (Baklouti, Gautier and Affes 2016), (Al-Tamimi 2012, Bredart 2014, Apergis, et.al 2019).

\section{2- Research problem, questions and objectives}

In spite of the fact that the prediction of financial distress has gained a lot of attention, our accepting of financial distress predicting is still incomplete. There are some research gaps in the literature that the 
Scientific Journal for Financial and Commercial Studies and Researches

(SJFCSR) Faculty of Commerce - Damietta University

present study is trying to fill. Most previous studies to date have focused on developing econometric models to predict financial distress in developed countries (see for example: Wang (2018), Tsai (2014), Baklouti et.al (2016), Al-Tamimi (2012), Bredart (2014), Chen (2008), Fich and Slezak (2008), Charalambakis and Garrett (2018), Baklouti, Gautier and Affes (2016), Abdullah, Ma'aji and Khaw (2016). Much less attention has been devoted to determine the nature of the relation between corporate governance and financial distress and whether qualified corporate governance practices can reduce the possibility of financial distress exposure. Bredart (2014) and Al-Tamimi (2012) described the relation between corporate governance and financial distress with under-investigated phenomenon. Indeed, to our knowledge there are very few empirical researches that address the above research point in the Egyptian context.

On the other hand, Lajili and Zeghal (2010) confirmed that a growing interest in corporate governance has been witnessed nowadays because of corporate scandals that have shocked the business community at the dawn of 21 st century. Based on the previous introduction, the current research tries to answer the following questions: what is the impact of board of directors' characteristics on financial distress? Does board of directors enhance the predictability of financial distress model? Which factor of board of directors has a major influence on financial distress?

The main aim(s) of the current research is to (1) classify firms included in my sample in to healthy and distressed firms. (2) Identify the impact of board of directors on financial distress. (3) Measure the board of directors' characteristics in research sample.

The rest of this paper is organized as follows: discussion of literature review and formulating hypotheses will be displayed in section (4), data and methodology will be presented in section no (5), results, analysis and discussion are displayed in section (6), and conclusions, implications and future research are displayed in section (7).

\section{3- Research limitations:}

For time and efforts limitations, this research investigated only three characteristics of board of directors. Other characteristics such as 


\section{Sarah Sobhy Mohamed Hassan}

board diversity, CEO gender are excluded from my research and this actually open the door for future research to investigate the other dimensions and its impact on financial distress probability.

\section{Literature review and hypotheses development:}

\section{A. Financial distress}

Over the last 40 years, financial distress prediction models have become vital research topic in finance major. An enormous amount of scholars from different countries all over the world have been scrutinizing financial distress topic depending on different statistical techniques (Balcaen and Ooghe 2004). Research in financial distress dates back to 1966 where Beaver depended on accounting ratios and changes in market prices to predict financial distress. Based on Beaver method, specific financial ratio of a firm should be compared with that ratio in another firm (benchmark) to discriminate between poor and healthy companies. Beaver depended on univariate analysis to predict financial distress. Literature in financial distress field have become widespread with different variables to predict financial distress. Some researchers have introduced financial distress models that combine accounting variables such as $\mathrm{Z}$ score model introduced by Altman in 1968 and O score model introduced by Ohlson in 1980. (Apergis, et.al 2019)

Altman (1968) overcame the weakness in the univariate analysis by introducing Multivariate discriminant analysis (MDA) .After that, in 1980 Ohlson criticized MDA because of its limited assumptions and introduced an alternative model called logit model. (Kristanti and Herwany 2017), (Charalambakis and Garrett 2018).

Recently, a lot of researchers investigate financial distress all over the world and they indicate different conclusions. Apergis, Bhattachage and Inekwe (2019) aimed at predicting financial distress in multinational corporations and investigating the impact of financial distress on performance. It showed that financial distress has negative influence on performance, employment and R\&D investment. Also, findings indicated that accounting data can predict financial distress in MNCs. Charalambakis and Garrett (2018) examined factors affecting financial distress in about 31000 Greek private firms depending on logit model. It 
Scientific Journal for Financial and Commercial Studies and Researches

(SJFCSR) Faculty of Commerce - Damietta University

concludes that profitability, retained earnings to total assets, tendency to pay dividends are negatively correlated with financial distress.

Wang (2018) investigated how accounting and non-accounting information influence financial distress. It collected data from private companies in Italy over the period starting from 2005-2009. It depended on some financial ratios such as: Firm's liquidity, solvency, profitability, activity and coverage ratio. Logistic regression was employed in this research. It concludes that the No of shareholders has a negative impact on financial distress in private companies in Italy.

Tsai (2014) examined the impact of financial ratios, market variables and governance on financial distress probability in Taiwan. It shows that corporate governance is more accurate than accounting ratios in predicting financial distress and managers have the incentive to manipulate financial ratios in accounting reports to hide some features of financial distress. Thus, accounting data reveal less information about distress than corporate governance. This research depends on Z-score model to evaluate each company's financial distress possibility. The research covers the period 2003-2009.

In the European Union, Baklouti, Gautier and Affes (2016) investigate the influence of governance on financial distress over the extended period from 2005-2011. The main governance characteristics taken in to account are as follows: board of directors, concentration of ownership and investor protection. Financial distress is measured using CAMEL indicator. This research shows that size of commercial banks is a basic factor of financial distress, also duality of CEO has a positive correlation with financial distress exposure.

Regarding developing econometric models which mixed financial, non-financial and governance data, Abdullah, Ma'aji and Khaw (2016) investigate financial distress in Malaysia. The sample consists of 172 companies (50\% non-failed and 50\% failed) over the period from 2000 2012. It shows that financial distress prediction model performs very well after incorporating corporate governance dimensions since the overall accuracy of the model has become $93.6 \%$. It also confirmed that No of directors, gender of managing director and controlling shareholders are significant predictors of financial distress. 


\section{Sarah Sobhy Mohamed Hassan}

On the other hand, some researchers introduced a comparison between companies regarding their practices of governance and also compare between their levels of financial distress Abdullah et.al (2015), Salloum and Azoury (2012) are from these researches. The main conclusion of these researches is that boards which have higher percentage of external directors are less exposed of financial distress.

In UAE, Al-Tamimi (2012) examines governance practices of banks and its impact on financial distress and corporate performance. It shows that: banks are aware of the importance of corporate governance dimensions, corporate governance practices are acceptable, there is significant positive correlation between governance and financial distress.

In the same direction of research Bredart (2014) introduces a new research, the sample consists of 312 companies from AMEX, NASDAQ and NYSE. The dimensions of corporate governance considered by this research are bored size, independence \& activity and CEO duality. It shows that corporate governance enhances the predicative ability of financial distress model.

Chen (2008) shows that the accuracy degree of the employed logit model has already enhanced by adding corporate governance as an exploratory variable.

Polsiri and Sookhanaphilibran (2009) developed distress prediction model considering corporate governance characteristics and financial variables in Thailand. It employed two important techniques; neural network and logit approach. Data are collected from non-financial companies in Thailand over a period starting from 1998 to 2001. It shows that corporate governance characteristics plays an important role in predicting financial distress. It finds that corporations with controlling shareholders existence in boards are less likely to be in distress.

Fich and Slezak (2008) investigate the ability of both corporate governance characteristics and financial information to predict financial distress in USA. It shows that governance characteristics increase ability to predict bankruptcy. In particular, large board of directors, depending more on inside directors and smaller equity ownership increases the probability to fill in bankruptcy. Also, Lajili and Zeghal (2010) examined 
Scientific Journal for Financial and Commercial Studies and Researches

(SJFCSR) Faculty of Commerce - Damietta University

the influence of corporate governance on bankruptcy in USA. A sample of financially distressed and healthy firms has been selected from USA from 2001-2003. Conclusion shows that corporate governance improves significantly the predictability of financial distress models. It also shows that financially distressed firms have higher directors' turnover, shorter outside director tenure.

\section{B. Corporate governance and financial distress:}

Corporate governance is a vital element in improving effectiveness and creating trust to attract investors especially after the collapse of a number of large companies (Zerban and Madani 2018). Dedication of board of directors and the desire of the higher management and subordinates to strengthen corporate governance have become a necessity. On the other hand, the failure to follow rules of corporate governance will rise operational risks and thus affect the interests of stakeholders. Zerban and Madani (2018).

Board of directors plays a vital role to reduce financial distress probability. As a result of this, poor governance practices of companies rise the probability that management will act against the interests of shareholders. Consequently, examining the impact of board of directors on financial distress has been searched by some scholars for example Abdullah, Azziz, Najd and Mohamed (2016) and Li et.al (2008) confirmed negative relation between the two variables. While Lee and Yeh (2004) confirmed positive relation between the same variables in Taiwan. However, some researchers showed mixed results for example Simpson and Gleason (1999) confirmed the negative association between CEO duality and financial distress while it shows insignificant relation between the no of insider directors and ownership by CEO.

\section{Board of directors}

Board of directors plays a vital role in explaining corporate governance internal mechanisms. To guarantee the effectiveness of decision-making process the board of directors develops, monitors and controls set of internal mechanisms (Noor and Iskander 2012). According to Luqman et.al (2018) the ability of the board of directors to work efficiently is a basic determinant of financial distress likelihood. Poor corporate governance will rise the opportunistic behaviours of managers 


\section{Sarah Sobhy Mohamed Hassan}

and will motivate them to make inconsistent decisions with maximizing firm's value. (Laporta et.al 2000).

\section{(A) Board independence}

The board independence refers to the separation of the chairman role and chief executive officer and the number of independent directors on board (Manzaneq et.al 2015, P.25).

\section{Separation of the roles of the chairman and the chief executive officer}

Reviewing literature of board independence reveals clear contradiction between supporters and opponents. Some researchers confirmed the usefulness of board independence since the split-up of the roles of the chairman and CEO is a necessity to ensure the independence of the board. (Baysinger and Hoskisson 2011). However, other researchers confirmed that duality (CEO duality) or gathering of powers of two persons in a single person is a necessity for facilitating leadership and reducing coordination costs.

On the relation between duality and financial distress, previous researchers reveal diverse results. Daily and Dalton (1994), Simpson and Gleason (1999) and Wang and Deng (2006) confirmed positive association between the two variables. However, Simpson and Gleason (1999) reveals negative influence between CEO duality and financial distress. Also, Chagnati et.al (1985) confirmed no relationship between distress and duality. Based on the previous discussion, I formulated the following hypothesis:

H1: The CEO duality is positively associated with financial distress.

\section{Number of independent directors}

Outside directors play a vital role in monitoring organizations and reducing agency costs. The existence of independent directors in boards became a necessity to solve information asymmetry problem and to adopt corporate governance practices. Also, the existence of independent outside directors help firms to make decisions which are aligned with shareholder's interests (Luqman et.al 2018). According to Fama and Jensen 1983; Jensen 1993, independent directors monitor the behaviours 
Scientific Journal for Financial and Commercial Studies and Researches (SJFCSR) Faculty of Commerce - Damietta University

of managers and prevent bad decisions that have a major effect on shareholders wealth maximization. Actually, empirical papers showed mixed results regarding the role of independent directors in corporations. On one hand, some research papers advocate the importance of independent directors since they represent the interests of shareholders (Brickley, Coles and Terry 1994).

Regarding the relation between financial distress and the pressure of outside directors, Wang and Deng (2006) confirmed that the existence of outside directors reduces financial distress. Consistent with the previous research, Chang (2009) confirmed that the presence of external directors on the board enable the corporation to detect opportunistic behaviours of managers. In contrary, Simpson and Gleason (1999) and Lajili and Zeghal (2010) found insignificant relation between financial distress and the external directors. Both Salloum and Azoury (2012) and Al-Tamimi (2012) confirmed that board of directors with outside directors is less willing to face financial distress. Elloumi and Gueyie (2001) scrutinized the board of directors of financially distressed firms and they found that distressed firms have fewer external directors than healthy firms. Based on the previous discussion, I formulated the second hypothesis to be as follows:

H2: A board with Independent directors is negatively associated with financial distress.

\section{Board size}

The board size refers to the total number of directors in a company (Abdullah 2004, P.65). Literature reveals two contradictory point of views regarding the suitable number of total directors in corporation (Morgan 2006). From one perspective, large boards attached to some problems such as involvement in strategic issues which has a negative impact on corporations' performance. In contrast to the above conclusion, the resource dependence theory confirms that there are many advantages in having larger boards. It enables companies to access to different kinds of information held by different managers and that are needed make decisions and achieve firms' organizations.

Regarding the relation between financial distress and board size, Salloum and Azoury (2012) confirmed empirically the existence of 


\section{Sarah Sobhy Mohamed Hassan}

negative relation between financial distress and board size. Also, Simpson and Gleason (1999) confirmed the negative association between the two variables.

H3: There is negative association between boards' size and financial distress.

\section{Data and methodology:}

\section{Data and sample:}

Data were collected from Egyptian stock exchange. The sample consists of all the companies included in EGX30 over the period 20152018. To get the financial data I depended on annual financial statements and the Co face Financial Yearbook.

\section{Methodology and measures of variables:}

For the best model to represent the data, two models are used in the current research logit model and multivariate discriminant analysis (MDA). Altman (1968) introduced his multivariate discriminant analysis (MDA) based on five financial ratios. Altman defined three major zones of financial distress: (1) Safe zone: Companies are located in this area if the value of $z$ is greater than 2.99. (2) Grey zone: If the value of $z$ fall between 1.81 and 2.99, then companies should be located in this area. (3) Distress zone: If the value of $\mathrm{z}$ is less than 1.81 then firms are located in distress area.

In 1993, Altman revised his model and replaced the fourth factor from market value of equity to total debts to book value of equity to total debts. This adjustment has resulted in some modifications in financial distress zones. If companies have $\mathrm{Z}$ score which is greater than 2.90 then these firms are located in safe zone. In grey zone, companies are located between 1.23 and 2.90 and in distress area $Z$ score is less than 1.23.

Altman and Hotchkiss (2010) renewed z score model once more to be consistent with emerging markets nature and this model known as Emerging markets score (EMS). Following Altman and Hotchkiss (2010), we will depend on z- score model specialized for emerging markets. The following table displays variables and measurements. 
Scientific Journal for Financial and Commercial Studies and Researches (SJFCSR) Faculty of Commerce - Damietta University

\begin{tabular}{|c|c|}
\hline \multicolumn{2}{|r|}{ Table (1) } \\
\hline \multicolumn{2}{|r|}{ Measurements } \\
\hline \multirow[t]{9}{*}{$\begin{array}{l}\text { Financial distress } \\
\text { (EMS) }\end{array}$} & $\begin{array}{l}\mathrm{EMS}=3.25+6.56 \quad \mathrm{X} 1 \quad+3.26 \mathrm{X} 2+ \\
6.72 \mathrm{X} 3+1.05 \mathrm{X} 4 .\end{array}$ \\
\hline & $\begin{array}{l}\mathrm{X} 1=\text { Working capital } \div \text { total assets, } \mathrm{X} 2=\text { Retained } \\
\text { earnings } \div \text { total assets. }\end{array}$ \\
\hline & $\begin{array}{l}\mathrm{X} 3=\text { EBIT } \div \text { total assets, } \mathrm{X} 4=\text { Book value of } \\
\text { equity } \div \text { total debt. }\end{array}$ \\
\hline & EMS: Overall score \\
\hline & Discrimination zones \\
\hline & Safe zone: EMS > 5.58. \\
\hline & Grey zone: $4.15<$ EMS $<5.58$ \\
\hline & Distress zone $<4.15$ \\
\hline & Source: Altman and Hotchkiss (2010), P.267 \\
\hline Board size & $\begin{array}{l}\text { Total number of members / directors on } \\
\text { company's board. }\end{array}$ \\
\hline CEO duality & $\begin{array}{l}\text { A dummy variable }(1,0), 1 \text { if the CEO is also the } \\
\text { chairman of the board otherwise } 0 .\end{array}$ \\
\hline $\begin{array}{l}\text { Board } \\
\text { independence }\end{array}$ & $\begin{array}{l}\text { No of non-executive directors } \div \text { Total no of } \\
\text { members }\end{array}$ \\
\hline \multirow[t]{3}{*}{ Control Variables } & * ROA \\
\hline & * Financial leverage: Total debt $\div$ total assets. \\
\hline & * Firm size: Natural logarithm of total assets. \\
\hline
\end{tabular}


Sarah Sobhy Mohamed Hassan

\section{Results, analysis and discussion:}

\section{A. Descriptive statistics}

Table (2)

\begin{tabular}{|c|c|c|c|c|c|c|c|}
\hline \multirow{12}{*}{$\begin{array}{l}\text { Healthy } \\
\text { firms }\end{array}$} & & $\begin{array}{l}\text { Log } \\
\text { assets }\end{array}$ & Leverage & ROA & $\begin{array}{l}\text { Board } \\
\text { size }\end{array}$ & $\begin{array}{c}\text { CEO } \\
\text { duality }\end{array}$ & $\begin{array}{c}\text { Board } \\
\text { independ } \\
\text { ence }\end{array}$ \\
\hline & $\mathrm{N} \quad$ valid & 224 & 224 & 224 & 224 & 224 & 224 \\
\hline & missing & 0 & 0 & 0 & 0 & 0 & 0 \\
\hline & Mean & 7.3633 & 0.4474 & 0.0316 & 10.37 & .77 & 72.4241 \\
\hline & Median & 7.0239 & 0.4570 & 0.0174 & 10.00 & 1.00 & 78.0000 \\
\hline & Standard deviation & 1.2540 & 0.1854 & 0.0449 & $\begin{array}{c}3.54 \\
1\end{array}$ & .420 & 18.16673 \\
\hline & Skewness & 3.536 & .020 & 1.878 & .694 & -1.308 & -.584 \\
\hline & $\begin{array}{l}\text { Standard errors of } \\
\text { skewness }\end{array}$ & .163 & .163 & .163 & .163 & .163 & .163 \\
\hline & Kurtosis & 22.461 & -.998 & 6.533 & .028 & -.293 & -1.151 \\
\hline & $\begin{array}{l}\text { Standard error of } \\
\text { kurtosis }\end{array}$ & .324 & .324 & .324 & .324 & .324 & .324 \\
\hline & Minimum & 5.9653 & 0.0977 & -0.1219 & 5 & 0 & 40.00 \\
\hline & Maximum & 17.9375 & 0.8215 & 0.2507 & 19 & 1 & 92.00 \\
\hline \multirow{12}{*}{$\begin{array}{l}\text { Distresse } \\
\text { d firms }\end{array}$} & & & & & & & \\
\hline & $\mathrm{N} \quad$ valid & 80 & 80 & 80 & 80 & 80 & 80 \\
\hline & missing & 0 & 0 & 0 & 0 & 0 & 0 \\
\hline & Mean & $\begin{array}{c}6.93819573 \\
5212340\end{array}$ & $\begin{array}{l}.75015890 \\
9872782\end{array}$ & $\begin{array}{c}- \\
.00814500 \\
0000000\end{array}$ & 8.49 & .40 & 68.0250 \\
\hline & Median & $\begin{array}{c}6.963776 \\
93541232 \\
0 \\
\end{array}$ & $\begin{array}{c}.5268509 \\
9474912 \\
7 \\
\end{array}$ & $\begin{array}{c}- \\
.00045518 \\
7884790 \\
\end{array}$ & 7.00 & 0.00 & 70.0000 \\
\hline & Standard deviation & $\begin{array}{c}.471121706 \\
637208 \\
\end{array}$ & $\begin{array}{l}.53995193 \\
8817119 \\
\end{array}$ & $\begin{array}{l}.03021256 \\
8646399 \\
\end{array}$ & 3.511 & .493 & 15.87688 \\
\hline & Skewness & .083 & 1.007 & -1.192 & .384 & .416 & .106 \\
\hline & $\begin{array}{l}\text { Standard errors of } \\
\text { skewness }\end{array}$ & .269 & .269 & .269 & .269 & .269 & .269 \\
\hline & Kurtosis & -1.374 & -.250 & 1.579 & -1.204 & -1.874 & -.661 \\
\hline & $\begin{array}{l}\text { Standard deviation } \\
\text { of Kurtosis }\end{array}$ & .532 & .532 & .532 & .532 & .532 & .532 \\
\hline & Minimum & $\begin{array}{c}6.264361 \\
72308592 \\
00 \\
\end{array}$ & $\begin{array}{c}.1773956 \\
3544315 \\
40 \\
\end{array}$ & $\begin{array}{c}- \\
.11354519 \\
01574950 \\
\end{array}$ & 4 & 0 & 40.00 \\
\hline & Maximum & $\begin{array}{c}7.700865 \\
19795047 \\
00\end{array}$ & $\begin{array}{c}1.909994 \\
5963354 \\
400 \\
\end{array}$ & $\begin{array}{c}.0544886 \\
1888093 \\
63 \\
\end{array}$ & 14 & 1 & 93.00 \\
\hline
\end{tabular}

Table (2) presents descriptive statistics of the major independent variables. It seems that the board size is smaller in highly distressed firms (8.49 directors) than their counterparts (10.37 directors). The CEO also plays the role of chairman of the board in $77 \%$ of the healthy firms and in 
Scientific Journal for Financial and Commercial Studies and Researches (SJFCSR) Faculty of Commerce - Damietta University

$44 \%$ of the distressed firms. Regarding board independence, it can be seen clearly that the degree of board independence in healthy firms is higher than distressed firms, whereas healthy firms have independent board members in the range of $72 \%$, the distressed firms depend on independent board directors in the range of $68 \%$.

Regarding control variables, table (2) shows that the company size in healthy firms, with an average of 7.36, is much higher than company size of distressed firms, with an average of 6.9. It can be seen clearly from table (2) that the proportion of debt that healthy firms depends on is much lower than the proportion that distressed companies depend on. The leverage ratio for healthy firms is only $44.7 \%$, while distressed firms rely more than $75 \%$ on debt. As for profitability, the return on assets (ROA) averaged $31.6 \%$ for healthy firms while distressed firms amounted to $-0.008 \%$.

B. Testing the difference between group of health companies and companies in distress using Mann-Whitney Test.

Table (3)

\begin{tabular}{|c|l|c|c|c|c|}
\hline \multicolumn{2}{|c|}{ group } & N & Mean Rank & Z & $\begin{array}{c}\text { Asymp. Sig. } \\
\text { (2-tailed) }\end{array}$ \\
\hline log assets & Healthy & 224 & 159.31 & -2.260 & .024 \\
\hline & Distressed & 80 & 133.44 & & \\
\hline leverage & Healthy & 224 & 140.40 & -4.017 & .000 \\
\hline & Distressed & 80 & 186.39 & & \\
\hline ROA & Healthy & 224 & 177.92 & -8.436 & .000 \\
\hline & Distressed & 80 & 81.34 & & .000 \\
\hline Board size & Healthy & 224 & 163.58 & -3.700 & \\
\hline & Distressed & 80 & 121.48 & & .043 \\
\hline $\begin{array}{c}\text { Board } \\
\text { independence }\end{array}$ & Healthy & 224 & 158.60 & -2.027 & \\
\hline & Distressed & 80 & 135.43 & & \\
\hline
\end{tabular}

Mann-Whitney test is used to study the difference between two separate sets whose data do not follow normal distribution. Regarding to the size of the company and board independence, table (3) shows that there are significant differences between healthy firms and distressed firms at $95 \%$ confidence and this difference is in favour of healthy firms. As for the size of board of directors, the financial leverage and returns on investments in assets, table (3) also shows that there are significant differences between the two groups at $99 \%$ confidence level. 
Sarah Sobhy Mohamed Hassan

\section{Correlation matrix}

Table (4)

\begin{tabular}{|c|c|c|c|c|c|c|c|}
\hline \multirow[t]{2}{*}{ Log assets } & $\begin{array}{c}\text { Pearson } \\
\text { Correlatio } \\
n \\
\end{array}$ & $\begin{array}{c}\log \\
\text { asset } \\
\text { s } \\
\end{array}$ & $\begin{array}{c}\text { leverag } \\
\text { e }\end{array}$ & ROA & $\begin{array}{l}\text { Boar } \\
\text { d size }\end{array}$ & $\begin{array}{c}\text { CEO } \\
\text { dualit } \\
y \\
\end{array}$ & $\begin{array}{c}\text { Board } \\
\text { independenc } \\
\mathrm{e} \\
\end{array}$ \\
\hline & $\begin{array}{l}\text { Sig. (2- } \\
\text { tailed) }\end{array}$ & 1 & -.081 & $.249^{*}$ & $.176^{* *}$ & $-.128-^{*}$ & $-.125-^{*}$ \\
\hline \multirow[t]{2}{*}{ Leverage } & $\begin{array}{c}\text { Pearson } \\
\text { Correlation } \\
\end{array}$ & & .157 & .000 & .002 & .026 & .029 \\
\hline & $\begin{array}{l}\text { Sig. (2- } \\
\text { tailed) }\end{array}$ & -.081 & 1 & $. \bar{*} 86-$ & $-.499-$ & .063 & $-.364-^{* *}$ \\
\hline \multirow[t]{2}{*}{ ROA } & $\begin{array}{c}\text { Pearson } \\
\text { Correlation }\end{array}$ & .157 & & .000 & .000 & .277 & .000 \\
\hline & $\begin{array}{c}\text { Sig. (2- } \\
\text { tailed) }\end{array}$ & $.249^{*}$ & $-.386-^{* *}$ & 1 & $.134^{*}$ & -.001 & .022 \\
\hline \multirow[t]{2}{*}{ Board size } & $\begin{array}{c}\text { Pearson } \\
\text { Correlation }\end{array}$ & .000 & .000 & & .020 & .982 & .703 \\
\hline & $\begin{array}{l}\text { Sig. (2- } \\
\text { tailed) }\end{array}$ & $.176^{*}$ & $-.499-^{* *}$ & $.134^{*}$ & 1 & .084 & $.383^{* *}$ \\
\hline \multirow[t]{2}{*}{ CEO duality } & $\begin{array}{c}\text { Pearson } \\
\text { Correlation } \\
\end{array}$ & .002 & .000 & .020 & & .144 & .000 \\
\hline & $\begin{array}{l}\text { Sig. (2- } \\
\text { tailed) }\end{array}$ &. $\bar{*}$ & .063 & -.001 & .084 & 1 & $-.174-^{* *}$ \\
\hline \multirow[t]{2}{*}{$\begin{array}{l}\text { Board } \\
\text { independence }\end{array}$} & $\begin{array}{c}\text { Pearson } \\
\text { Correlation } \\
\end{array}$ & .026 & .277 & .982 & .144 & & .002 \\
\hline & $\begin{array}{l}\text { Sig. (2- } \\
\text { tailed) }\end{array}$ & 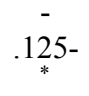 & $-.364-^{* *}$ & .022 & $.383^{* *}$ & $-.174-$ & 1 \\
\hline & & .029 & .000 & .703 & .000 & .002 & \\
\hline \multicolumn{8}{|c|}{ Correlation is significant at the 0.01 level (2- tailed) } \\
\hline \multicolumn{8}{|c|}{ Correlation is significant at the 0.05 level (2- tailed) } \\
\hline
\end{tabular}

Correlations between all the variables included in the model are presented in Table (4). Table (4) shows that the correlation coefficients between independent variables are low to average, which means that there is no multicollinearlty problem. 
Scientific Journal for Financial and Commercial Studies and Researches (SJFCSR) Faculty of Commerce - Damietta University

\section{Logistic regression}

Table (5)

\begin{tabular}{|c|c|c|c|c|}
\hline & & Chi-square & df & Sig. \\
\hline Step 1 & Step & 142.771 & 6 & .000 \\
\hline & Block & 142.771 & 6 & .000 \\
\hline & Model & 142.771 & 6 & .000 \\
\hline
\end{tabular}

Table (6)

\begin{tabular}{|l|c|c|c|}
\hline Step & -2 Log likelihood & $\begin{array}{c}\text { Cox \& Snell R } \\
\text { Square }\end{array}$ & $\begin{array}{c}\text { Nagelkerke R } \\
\text { Square }\end{array}$ \\
\hline 1 & $207.640^{\mathrm{a}}$ & .375 & .548 \\
\hline
\end{tabular}

Table (7)

Classification table

\begin{tabular}{|c|c|c|c|c|c|}
\hline \multirow{3}{*}{\multicolumn{3}{|c|}{ Observed }} & \multicolumn{3}{|c|}{ Predicted } \\
\hline & & & \multicolumn{2}{|c|}{ group } & \multirow{3}{*}{$\begin{array}{c}\text { Percentage } \\
\text { Correct }\end{array}$} \\
\hline & & & smrif ythlaeh & $\begin{array}{c}\text { smrif } \\
\text { dessertsid }\end{array}$ & \\
\hline \multirow{3}{*}{ Step 1} & \multirow{2}{*}{ group } & smrif dessertsid & 207 & 17 & \\
\hline & & smrif ythlaeh & 34 & 46 & 57.5 \\
\hline & \multicolumn{2}{|c|}{ Overall Percentage } & & & 83.2 \\
\hline
\end{tabular}

Table (8)

Variables in equation

\begin{tabular}{|l|l|c|c|c|c|c|c|}
\hline & & B & S.E. & Wald & df & Sig. & Exp(B) \\
\hline Step 1 & log assets & -1.029 & .337 & 9.347 & 1 & .002 & .357 \\
\hline & leverage & 2.135 & .723 & 8.723 & 1 & .003 & 8.453 \\
\hline & ROA & -27.724 & 8.369 & 10.975 & 1 & .001 & .000 \\
\hline & Board size & .018 & .058 & .096 & 1 &. $\mathbf{7 5 7}$ & 1.018 \\
\hline & $\begin{array}{l}\text { CEO } \\
\text { duality(1) }\end{array}$ & 3.049 & .503 & 36.776 & 1 & .000 & 21.089 \\
\hline & BI & -.048 & .016 & 9.551 & 1 & .002 & .953 \\
\hline & Constant & 7.258 & 2.946 & 6.070 & 1 & .014 & 1419.435 \\
\hline
\end{tabular}




\section{Sarah Sobhy Mohamed Hassan}

As it is shown from table 5, the model is significant, with value of chi-square 142.771 at a significance level of $99 \%$. Table (6) also shows that $\mathrm{R}^{2}$ is $54.8 \%$, which means that the model explains $54.8 \%$ of the changes in financial distress. Table (7) shows that the model classified the data to a group of health companies and a group of highly distressed companies of $83.2 \%$ correctly. Table (8) reveals the significance of the variables included in the model. The table shows that the board independence and CEO duality have significant impact on financial distress at a 99\% confidence level, it shows that CEO duality has a positive impact on financial distress. This implies that increasing duality will increase financial distress probability. Accordingly, I should accept hypothesis (1) stating that" The CEO duality is positively associated with financial distress". On the other hand, board independence has a significant negative impact on financial distress which implies that depending on independent directors heavily will decrease financial distress. According to this conclusion, I should accept hypothesis 2 stating that "A board with Independent directors is negatively associated with financial distress". Board size is insignificant variable in financial distress probability, which means that we should refuse hypothesis 3 states that:" There is positive association between boards' size and financial distress".

The previously indicated results confirm that adding board of director's characteristics to financial distress econometric models enhance the predictability of these models and this conclusion adds to the literature body. The research evidence that CEO duality is positively associated with financial distress probability actually meets my expectations and is in line with previous empirical researches (see for example: Daily and Dalton (1994), Simpson and Gleason (1999) and Wang and Deng (2006) and varies with Simpson and Gleason (1999) which reveals negative influence between CEO duality and financial distress. Also, Chagnati et.al (1985) confirmed that there is no relationship between distress and duality. The hypothesis related to board independence and its impact on financial distress has been confirmed which implies that my expectation has already been met. This result confirms the conclusion of different empirical studies (See for example: Wang and Deng (2006), Chang (2009), Salloum and Azoury 
Scientific Journal for Financial and Commercial Studies and Researches (SJFCSR) Faculty of Commerce - Damietta University

(2012) and Al-Tamimi (2012) Elloumi and Gueyie (2001). However, the result of my second hypothesis varies with Elloumi and Gueyie (2001).

Regarding the third hypothesis related to the relationship between board size and occurrence of financial distress, the conclusion has not lead to significant result. In contrary to our results, some previous studies confirmed the negative association between the two variables. (See for example: Salloum and Azoury (2012) and Simpson and Gleason (1999).

\section{Graph (1)}

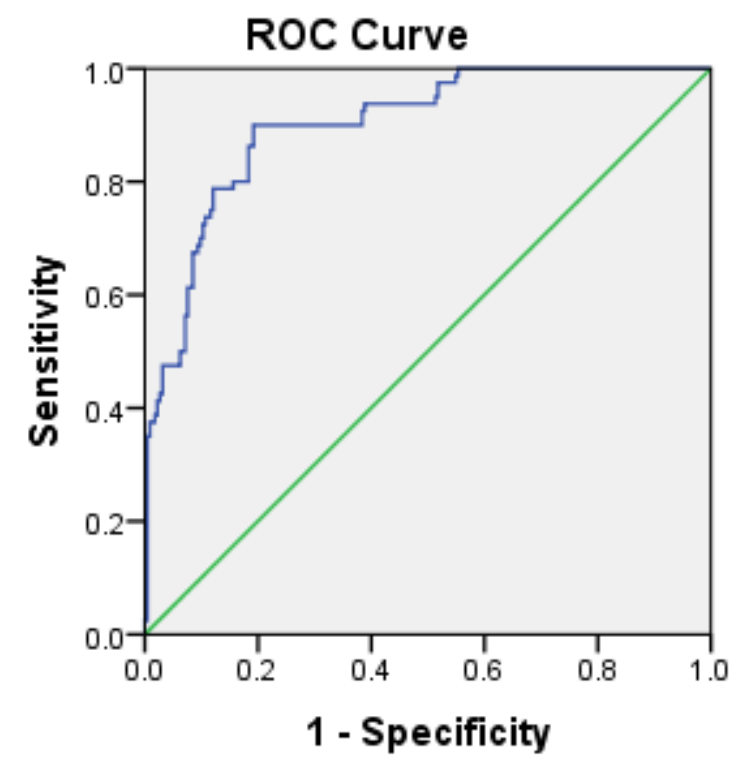

\begin{tabular}{|c|c|c|c|c|}
\hline \hline \multirow{2}{*}{ Area } & \multirow{2}{*}{$\begin{array}{c}\text { Std. } \\
\text { Error }^{\mathbf{a}}\end{array}$} & \multirow{2}{*}{ Asymptotic Sig. } & \multicolumn{2}{|c|}{$\begin{array}{c}\text { Asymptotic 95\% Confidence } \\
\text { Interval }\end{array}$} \\
\cline { 4 - 5 } & & & Lower Bound & Upper Bound \\
\hline .900 & .019 & .000 & .863 & .937 \\
\hline
\end{tabular}

Diagram shows that the area under the curve is $90 \%$ which means that the model classifications of data is not due to chance. 
Sarah Sobhy Mohamed Hassan

$\underline{\text { E. Discriminant model Summary of canonical discriminant functions }}$

Table (9)

Eigenvalues

\begin{tabular}{|c|c|c|c|c|}
\hline Function & Eigenvalue & $\begin{array}{c}\text { \% of } \\
\text { Variance }\end{array}$ & Cumulative \% & $\begin{array}{c}\text { Canonical } \\
\text { Correlation }\end{array}$ \\
\hline 1 & $.609^{\mathrm{a}}$ & 100.0 & 100.0 & .615 \\
\hline
\end{tabular}

a. First 1 canonical discriminant functions were used in the analysis.

\section{$\underline{\text { Table(10) }}$}

Wilks' Lambda

\begin{tabular}{|c|c|c|c|c|}
\hline $\begin{array}{c}\text { Test of } \\
\text { Function(s) }\end{array}$ & $\begin{array}{c}\text { Wilks' } \\
\text { Lambda }\end{array}$ & Chi-square & df & Sig. \\
\hline 1 & .621 & 142.271 & 6 & .000 \\
\hline
\end{tabular}

From tables (9), (10), it appears that $\mathrm{R}^{2}$ in the model explains $38.5 \%$ of the predicted changes in financial distress, which is less than $\mathrm{R}^{2}$ in logistic model.

Table (11)

$\underline{\text { Standardized canonical discriminant }}$

Functions coefficients

\begin{tabular}{|l|c|}
\hline \multirow{2}{*}{} & Function \\
\cline { 2 - 2 } & 1 \\
\hline log assets & .325 \\
\hline leveage & -.559 \\
\hline ROA & .459 \\
\hline Board size & -.112 \\
\hline CEO duality & .798 \\
\hline Board independence & .227 \\
\hline
\end{tabular}

226 Vol. 3, No. 1, Part 1, Jan 2022 
Scientific Journal for Financial and Commercial Studies and Researches (SJFCSR) Faculty of Commerce - Damietta University

The regression coefficients for the variables in the model, whether control variables or explanatory variables, are shown in table 11. All the variables included in the model appear to be significant. According to table (11) CEO duality has a significant and positive impact on financial distress which means that we should accept hypothesis 1 stating that "The CEO duality is positively associated with financial distress". This result is in line with some previous research such as Daily and Dalton (1994), Simpson and Gleason (1999) and Wang and Deng (2006) and varies with Simpson and Gleason (1999) which reveals negative influence between CEO duality and financial distress. Also, Chagnati et.al (1985) confirmed that there is no relationship between distress and duality. Board size has a negative significant impact on financial distress which means that we should reject hypothesis no 3." There is a positive association between boards' size and financial distress". Some previous papers have shown the same negative association such as Salloum and Azoury (2012) and Simpson and Gleason (1999). Results showed that depending on higher percentage of outside directors will increase the probability of financial distress, so we should accept hypothesis no 2 states that "A board with Independent directors is negatively associated with financial distress". This conclusion is in line with Elloumi and Gueyie (2001). However it varies with some other studies such as Wang and Deng (2006), Chang (2009), Salloum and Azoury (2012) and Al-Tamimi (2012) Elloumi and Gueyie (2001).

As it shows clearly from table (11), all the control variables have a significant impact on financial distress. Financial leverage has a negative impact while the other control variables have a positive impact.

Table (12)

Functions at Group Centroids

\begin{tabular}{|l|c|}
\hline \multirow{2}{*}{\multicolumn{1}{c}{ group }} & Function \\
\cline { 2 - 2 } & 1 \\
\hline smrif ythleah & .465 \\
\hline smrif dessertsid & -1.302 \\
\hline
\end{tabular}




\section{Sarah Sobhy Mohamed Hassan}

Table (12) shows the cut-off points on which to determine whether or not the company is in distress.

\section{Graph (2)}

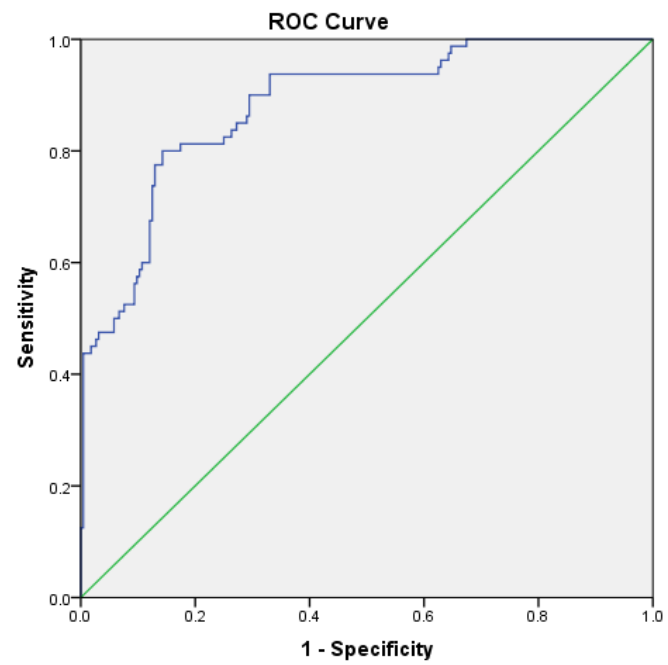

Area Under the Curve

Test Result Probabilities of Membership in Variable(s): $\quad$ Group 2 for Analysis 1

\begin{tabular}{|c|c|c|c|c|}
\hline \multirow{2}{*}{ Area } & & \multirow{2}{*}{$\begin{array}{c}\text { Asymptotic 95\% } \\
\text { Std. Error }\end{array}$} & $\begin{array}{c}\text { Asymptotic } \\
\text { Sig. }\end{array}$ & \multicolumn{2}{c|}{$\begin{array}{c}\text { Asfidence Interval } \\
\text { Confing }\end{array}$} & $\begin{array}{c}\text { Lower } \\
\text { Bound }\end{array}$ & $\begin{array}{c}\text { Upper } \\
\text { Bound }\end{array}$ \\
\hline .882 & .022 & .000 & .840 & .925 \\
\hline
\end{tabular}

a. Under the nonparametric assumption

b. Null hypothesis: true area $=0.5$ 
Scientific Journal for Financial and Commercial Studies and Researches

(SJFCSR) Faculty of Commerce - Damietta University

Diagram shows that the area under the curve is $88.2 \%$ which means that the model classifications of data is not due to chance. However, when comparing the area under the curve in the logit model with the discriminant analysis model, we can see that the logit model is better at classifying data.

\section{Conclusion, implications and future research}

According to literature, most researches have shed lights on analysing financial distress in specific industries or sectors in advanced countries. Also, literature confirmed that examining financial distress is important in different economies and especially in developing counties. This article is one of the first to investigate whether board of directors' attributes contribute to explain of the occurrence of financial distress in the context of Egypt's economy. Our results suggest board size is smaller in highly distressed firms, also CEO plays the role of chairman (duality) in the majority of healthy firms (77\% in healthy firms and $44 \%$ of the distressed firms). The degree of board independence in healthy firms is higher than distressed firms. Company size in healthy firms is much higher than company size of distressed firms. Additionally, the percentage of debt in healthy firms is much lower than the same percentage in distressed firms. Measures of profitability are higher in healthy firms than in distressed firms.

On the other hand, conclusions of the current research confirmed that the proportion of independent directors and CEO duality are found to be significant determinants for financial distress. However, board size is not a significant variable in predicting financial distress. These results have been confirmed using logistic model. On the other hand, discriminant model reveals that all the explanatory variables are significant in explaining financial distress. Increasing board size increases the probability of financial distress while CEO duality and board independence have a positive impact on financial distress probability. Depending on different criteria $\left(\mathrm{R}^{2}\right.$, classification table, $\mathrm{ROC}$ curve) to compare between logit model and discriminant model, it has been revealed that logit model is better in explaining financial distress.

The current research has managerial and theoretical implications. Firstly, adding board of directors' characteristics has actually enhanced 


\section{Sarah Sobhy Mohamed Hassan}

the predictability of financial distress models and consequently it adds to literature. More attention should be paid to CEO duality and board independence, as the current research introduces a new evidence that those variables have a major significant impact on financial distress. Secondly, the findings can be useful for different parties for example; managers, investors, and creditors. Regarding managers, the findings of the current research can help managers to avoid financial distress by providing them with early signals of performance decline. For investors, examining the main factors that might lead to financial distress is an important requirement to avoid investing in distressed firms. Firms' evaluation is an important task for creditors, and they should consider factors of distress to avoid losses.

Future research may include analysis of financial distress in banking sector in the Egyptian context, as my research has excluded banking and financial institutions for their especial nature. Also, more attention could be devoted to developing more comprehensive models of financial distress especially in emerging markets, as financial distress models employed by the current research depended only on accounting data. Also, comparing between different financial distress would enhance the predictability of these models.

\section{Reference list:}

1. Abdullah, N., Ma'aji,M.,Khaw,K., (2016), "The value of governance variables in predicting financial distress among small and medium sized enterprises in Malaysia, Journal of Accounting and Finance.Vol.12, No.1, PP.77-91.

2. Al-Tamimi, H.,(2012)"The effects of corporate governance on performance and financial distress The experience of UAE national banks", Journal of Financial Regulation and Compliance, Vol.20, No.2, PP.169-181.

3. Altman, E., (1968). Financial ratios, discriminant analysis and the prediction of corporate bankruptcy. Journal of Finance. Vol.23. PP.589-609.

4. Altman, E., (1988). Statistics in medical journals. Vol. 1. PP.59-71.

5. Altman, E., Hotchkiss,E.,(2010).Corporate financial distress and bankruptcy: Predict and avoid bankruptcy, analyse and invest in distressed debt. Volume 289. John Wiley \& Sons. 
Scientific Journal for Financial and Commercial Studies and Researches (SJFCSR) Faculty of Commerce - Damietta University

6. Apergis,N., Bhattacharya,M., \& Inekwe,J., (2019): Prediction of financial distress for multinational corporations: Panel estimations across countries, Applied Economics, Applied Rconomics, PP. 14664283.

7. Baklouti, N., Gautier, F., Affes, H., (2016). Corporate governance and financial distress of European commercial banks. Journal of Business Studies Quarterly. Vol. 7.PP.75-96.

8. Balcaen, S and Ooghe, H., (2004). Alternative methodologies in studies on business failure: do they produce better results than the classic statistical methods? Engineering.Vol.33.PP.1-35.

9. Beaver, W., (1966). Financial ratios as predictors of failure. Journal of Accounting and Research, Vol.4, PP. 74-111.

10. Beaver, W., (1966). The information content of annual earnings announcement. Journal of Accounting Research. Vol.6. PP.67-92.

11. Blazy, R.,Nigam,N.,(2018)" Corporate insolvency procedures in England: the uneasy case for liquidations", European Journal of Law and Economics, PP.

12. Brédart, X., (2014) "Financial Distress and Corporate Governance: The Impact of Board Configuration", International Business Research; Vol. 7, No. 3; PP.72-80.

13. Chacanti,R., Mahajan,V.,Sharma, S.,(1985),"Corporate board size, composition and corporate failure in retailing industry", Journal of Management studies, Vol.22, No.4, PP.400-417.

14. Chen, H., (2008). The timescale effects of corporate governance measure on predicting financial distress. Vol. 11. PP.35-46.

15. Daily,C., and Dalton, D., (1994)," Bankruptcy and Corporate Governance: The Impact of Board Composition and Structure",? Academy of Management Journal, Vol.37, No.6, PP.1603-1617.

16. Deng, X., and Wang,Z., (2006) "Ownership structure and financial distress: Evidence from public-listed companies in China", International Journal of Management, Vol. 23,No. 3, PP.486.

17. Fama, E. \& Jensen, M. (1983) Separation of ownership and control. Journal of Law and Economics, 26, 301-325.

18. Fich,E., Slezak,S.,(2008), Can corporate governance save distressed firms from bankruptcy? An empirical analysis, Rev Quant Finan Acc, Vol.30, PP. 225-251 


\section{Sarah Sobhy Mohamed Hassan}

19. Hermalin, B., \& Weishbach, M. (1988). The determinants of board composition. Rand Journal of Economics, 19(4), 589-606.

20. Hillman, A. J., \& Dalziel, T. (2003). Boards of directors and firm performance: Integrating agency and resource dependency perspectives. academy of Management Review, 28(3),383-396.

21. Jabeur,S., and Fahmi, Y., (2017)," Forecasting financial distress for French firms: a comparative study",

22. Kristanti, F., and Herwany, A., (2017)"Corporate Governance, Financial Ratios, Political Risk and Financial Distress: A Survival Analysis " Accounting and Finance Review, Vol.2, No.2, PP.26-43.

23. Lajili,K., and Ze'gha,D., (2010), "Corporate governance and bankruptcy filing decisions", Journal of General Management Vol. 35 No. 4 Summer,PP.3-26.

24. Lee,T., and Yeh,Y., (2004),"Corporate governance and financial distress: Evidence from Taiwan, Vol.12, No.3, PP. 378-388.

25. Li, H., (2018). Financial distress prediction based on serial combination of multiple classifiers. Expert System with Application. Vol.36. PP. 8659-8666.

26. Liang, D., Tsai, C., Chang, L., (2020) Combining corporate governance indicators with stacking ensembles for financial distress prediction. Journal of Business Research. Vol. 120. PP.137-146.

27. Luqman, R., Ul hassan, M., Tabasum,S., Khakwani,M., and Irshad,S.,(2018),probability of financial distress and proposed adoption of corporate governance structures: Evidence from Pakistan, Cogent Business \& Management ,No.5,

28. Manzaneque, M., Priego, A., and Merino, E., (2015), corporate governance effect on financial distress likelihood: Evidence from Spain, Spanish Accounting Review, Vol.XX, No.XXX, PP.1-11.

29. Noor,Z., and Iskandar,T., (2012) "Corporate governance and corporate failure: A survival analysis", Prosiding Persidangan Kebangsaan Ekonomi Malaysia Ke VII, PP.684-695.

30. Salloum, C., Schmitt, C., and Bouri, E., (2012)" Does board structure affect financial distress? A study with reference to family firms in Lebanon", Investment Management and Financial Innovations, Volume 9, Issue 4, PP. 113-123. 
Scientific Journal for Financial and Commercial Studies and Researches (SJFCSR) Faculty of Commerce - Damietta University

31. Salloum,C., and Azoury, N., (2012) "Corporate governance and firms in financial distress: Evidence from a middle eastern country", International Journal of Business Governance and Ethics, Vol.7,No.1,PP.1-17.

32. Shahwan, T., (2015). The effects of corporate governance on financial performance and financial distress: evidence from Egypt, Vol.15, No.5, PP. 641-662.

33. Simpson, W., Gleason, A., (1999). Board structure, Ownership, and financial distress in banking sector. International Review of Economics and Finance. Vol. 8. PP.281-292.

34. Tsai, C., (2014). Combining cluster analysis with classifier ensembles to predict financial distress. Information Fusion. Vol.16. PP. 46-58.

35. Zebran, A., Madani, A., (2018). Corporate governance and board of director's responsibility in appointing senior managers: A case in Saudi Arabia. International Journal of Business and Management. Vol.13. PP.1-7. 
الهدف: يهدف البحث الحالي التعرف على طبيعة العلاقة بين العسر المـالي وخصائص

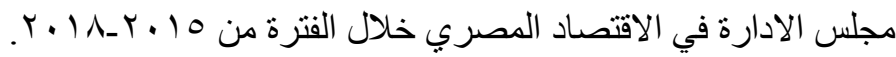
تصميم البحث / المنهجيت / المدخل: تم الاعتماد على نموذجين في البحث الحالي. النموذج الأول هو نموذج التحليل المتمـيز المقدم من Altman and Hotchkiss و النموذج الماعي

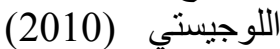

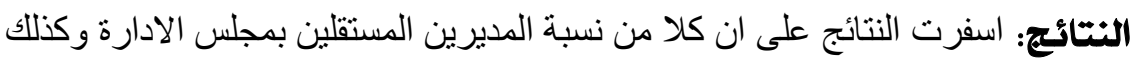

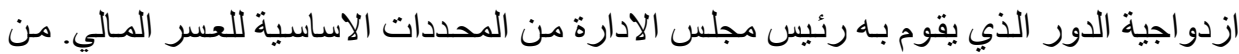

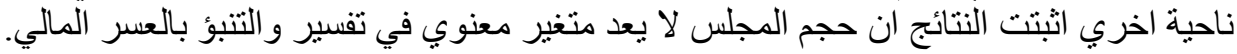

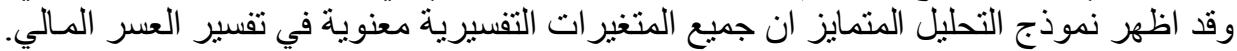

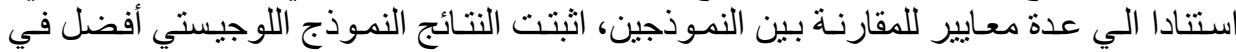

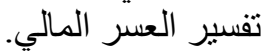

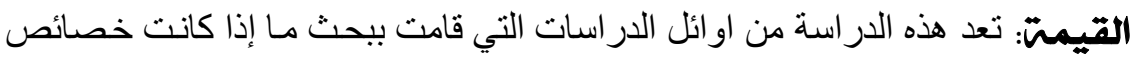
مجلس الادارة تساهم في تفسير حدوث العدر العر المالي في الاقتصاد المصري.

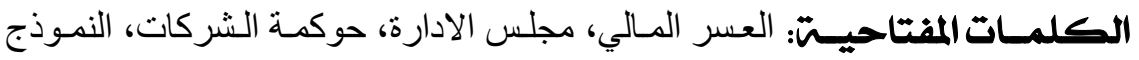
اللوجيستي، نموذج التحليل المتمايز. 